\title{
格子ボルツマン法の多粒子分散系への適用*
}

\author{
佐 藤 明*1， Roy W. CHANTRELL*2
}

\section{Application of the Lattice Boltzmann Method to Many Particle Dispersions}

\author{
Akira SATOH*3 and Roy W. CHANTRELL \\ ${ }^{* 3}$ Faculty of Systems Science and Technology, Akita Prefectural University, \\ 84-4 Ebinokuchi, Tsuchiya-aza, Yuri-honjo-shi, Akita, 015-0055 Japan
}

\begin{abstract}
We have discussed the feasibility of the lattice Boltzmann method as a simulation technique with multi-body hydrodynamic interactions for many particle dispersions, by considering aggregation phenomena in a two-dimensional suspension composed of magnetic particles. The results obtained here are summarized as follows. The density ratio between magnetic particles and the ambient liquid does not significantly influence the cluster formation. If relatively coarse lattices are used, physically reasonable aggregate structures can be obtained, but if fine lattices are adopted, the particle Brownian motion cannot be activated properly, which causes invalid aggregate formation of particles. We may conclude that, if relatively coarse lattice systems are used, the translational and rotational Brownian motion of particles is reasonably activated, but if fine lattice system are adopted, the lattice Boltzmann method cannot give rise to physically reasonable results.
\end{abstract}

Key Words: Lattice Boltzmann Method, BGK Collision Model, Particle Dispersions, Boundary Conditions, Aggregation Phenomena, Pair Correlation Function

\section{1.}

高分子溶液 ${ }^{(1)}$ や微粒子が分散した粒子サスペンショ ン系 ${ }^{(2,3)}$ を対象とした場合，高分子や懸濁粒子の多体流 体力学的な相互作用を考慮したシミュレーションを行 うこ上は現在でもかなり困難である。これは溶媒分子々 高分子や懸濁粒子の運動の特性時間の著しい相違に主 に基づいている、溶媒分子の特性時間ははるかに短いの で, 分子動力学法 ${ }^{(4.5)}$ を用いる場合には, シミュレーショ ンの時間きざみを分子の特性時間に合わせる必要があ るので, 高分子や懸濁粒子の運動を追跡することはほぼ 不可能になる. 従って, 溶媒分子を一様流体と見なし, 高分子や微粒子の連動方程式に組み込む方法が用いら れる.これがブラウン動力学法 ${ }^{(3,4)}$ であり，この場合，

流れ場を解くことはできず, 単純せん断流や伸張流など の与えられた線形流れ場での微粒子などの挙動を解明 することになる ${ }^{(3)}$. 固体球状粒子などの単純な微粒子の サスペンションでは, 多体流体力学的な相互作用を考慮 したブラウン動力学シミュレーションが可能であるが (3)，棒状粒子などの非球状粒子分散系のシミュレーショ ンは非常に困難となる。いずれにしても，この方法では

* 原稿受付 2009 年 2 月 23 日.

*1 正員, 秋田県立大学システム科学技術研究科(覀) 015-0055 由利本荘市土谷字海老ノ口84-4).

*2 Physics Department, The University of York (Heslington, York YO10 5DD, UK)

E-mail : asatoh@akita-pu.ac.jp
流れ場と粒子の挙動を同時に解くことは基本的に不可 能である。

流体の流れ場と精子の挙動を同時に追跡する従来の 方法として,まわりの流体を連続体として Navier-Stokes 方程式を解き, 粒子まわりの流れ場の解から粒子に作用 する力とトルクを計算し, 粒子の運動を追跡する方法が ある ${ }^{(6-8)}$. しかしながら，この方法では，粒子表面での すべり無しの条件を満足させること, 粒子に作用する力 およびトルクを流れ場の解から計算すること,ならびに， 粒子のブラウン運動の誘起に関して, 非常に大きな難点 があると言わざるを得ない。

一方，溶媒分子をある程度一まとめにして，その仮想 流体粒子の運動の特性時間が䀣濁粒子のそれと同程度 にする方法も考えられている.代表的な例は散逸粒子動 力学法 ${ }^{(9-13)}$ で, この方法の場合, このような仮想流体粒 子を散逸粒子と呼び, 散逸粒子同士は互いに運動量を交 換しながら近距㰚オーダーの斥力で相互作用し,ブラウ ン運動と類似のランダム運動を行う。

仮想流体粒子の概念を用いるもう一つの代表的な方 法は格子ボルツマン法(14,15)であり，散逸粒子動力学法と の大きな違いは，格子ボルツマン法では，仮想流体粒子 は与えられた速度で格子点上を移動し，各格子点での仮 想流体粒子の粒子分布関数を求めるというもので，仮想 流体粒子の速度を直接解くというものではない.このよ うな格子ボルツマン法は連続体の解析法として提案さ 
れ発展してきたが，粒子サスペンション系の場合，仮想 流体粒子の運動を介して懸濁粒子同士の流体力学的相 相互作用が実現できることが大きな特徴である.ただし， 㲘濁粒子のブラウン運動が物理的に十分妥当なレベル で誘起されるかどうかが重要な問題である。

本研究では，粒子の多体流体力学的相互作用を考慮し たシミュレーション法としての格子ボルツマン法の可 能性を詳細に検討することを目的とする。具体的には， 熱力学的平衡状態にある磁性粒子からなるコロイド分 散系の凝集現象を取り上げ, 微粒子のブラウン運動が物 理的に妥当な形で誘起されるかを，用いる格子の粗さや 仮想粒子と䀣濁粒子の密度比などを種々に変えて検討 する、結果の妥当性は，モンテカルロ法やブラウン動力 学法で得た結果と比較することで行う。

\section{2. 格子ボルツマン法}

\section{2・1 BGK 挌子ボルツマン法＼cjkstart格子ボルツマン} 法では,シミュレーション領域を図1(a) に示すように 格子状に見立て，仮想流体粒子が移動する場合必ず格 子点から格子点へと移動するようにする。本研究では， 2 次元の多粒子分散系の凝集現象老刘象とするので, 図 1(b)に示すD2Q9 モデル(14,15)を用いることにする. すなわち，仮想流体粒子は 8 通りの速度を持って近接 格子点八移動することが可能であり，静止状態も含め れば， $\alpha=0,1, \ldots, 8$ の 通りの速度が可能である. 格子 ボルツマン法における基礎方程式で最も重要な項は仮 想流体粒子の衝突処理の項である。この処理法によっ ていくつもの基礎方程式が存在するが，希薄気体のボ ルツマン法でも有名な BGK モデルを採用した BGK 格 子ボルツマン法をここでは採用する， $\alpha$ 方向の粒子分 布関数は, 反対方向の隣接格子点の $\alpha$ 方向の分布関数 にのみ依存し，他の格子点の分布関数に依存しない。 任意の格子点の位置ベクトルを $\boldsymbol{r}$ とし，時閒 $\boldsymbol{t}$ におけ る $a$ 方向の粒子分布関数を $f_{u}(r, t)$ とすると, $\Delta t$ 時間後 の粒子分布関数 $f_{a}\left(r+c_{\alpha} \Delta t, t+\Delta t\right)$ 法次式から求まる ${ }^{(14,15)}$.
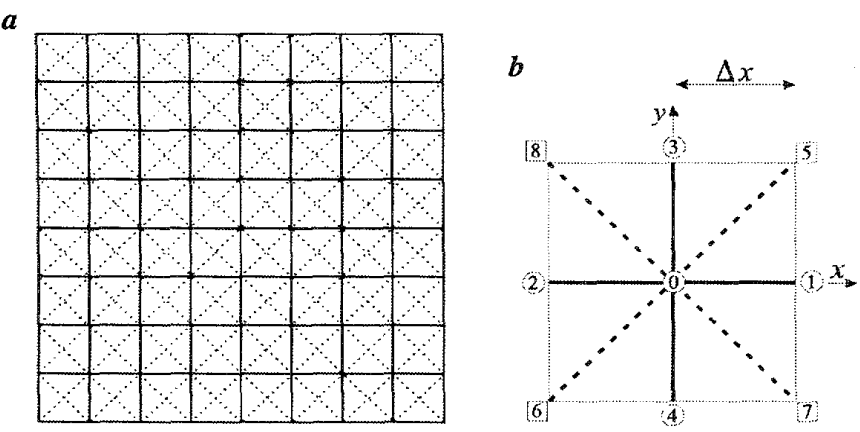

Fig.1 D2Q9 Model for Two-dimensional Lattice Boltzmann Simulations: (a) Lattice Model, and (b) Unit Cell for D2Q9 Model

$$
\left.\begin{array}{l}
f_{\alpha}\left(\boldsymbol{r}+c_{\alpha} \Delta t, t+\Delta t\right)=\tilde{f}_{\alpha}(\boldsymbol{r}, t) \\
\tilde{f}_{\alpha}(\boldsymbol{r}, t)=f_{\alpha}(\boldsymbol{r}, t)+\frac{1}{\tau}\left\{f_{\alpha}^{(0)}(r, t)-f_{\alpha}(\boldsymbol{r}, t)\right\}
\end{array}\right\}
$$

ここに，ては衝笑の緩和時間であり， $f_{a}^{(0)}$ は平衡分布 で，その点における巨視的な流体速度を $u$, 密度を $\rho$ と すれば，次のようになる。

$$
f_{\alpha}^{(0)}=\rho w_{\alpha}\left\{1+3 \frac{c_{\alpha} \cdot u}{c^{2}}-\frac{3 u^{2}}{2 c^{2}}+\frac{9}{2} \cdot \frac{\left(c_{\alpha} \cdot u\right)^{2}}{c^{4}}\right\}
$$

上式で， $w_{\alpha}$ は重み係数， $c_{\alpha}$ は格子速度で $\mathrm{D} 2 \mathrm{Q} 9$ モデ ルでは次のようになる。

$$
w_{\alpha}=\left\{\begin{array}{ll}
4 / 9 & \text { for } \alpha=0 \\
1 / 9 & \text { for } \alpha=1,2,3,4 \\
1 / 36 & \text { for } \alpha=5,6,7,8
\end{array}\left|c_{\alpha}\right|= \begin{cases}0 & \text { for } \alpha=0 \\
c & \text { for } \alpha=1,2,3,4 \\
\sqrt{2 c} & \text { for } \alpha=5,6,7,8\end{cases}\right.
$$

この式において，c恪子点間の移動速度で，単位格 子の一辺の長さを $\Delta x$, 時間きざみを $\Delta t$ とすれば， $c=\Delta x / \Delta t$ である.もし，各格子点における粒子分布関数 $f_{\alpha}(\alpha=0,1,2, \ldots, 8)$ が得られているなら，巨視的な密度 と運動量が次式から評価できる。

$$
\rho(\boldsymbol{r}, t)=\sum_{\alpha=0}^{8} f_{\alpha}(\boldsymbol{r}, t), \quad \rho(\boldsymbol{r}, t) \boldsymbol{u}(\boldsymbol{r}, t)=\sum_{\alpha=0}^{8} f_{\alpha}(\boldsymbol{r}, t) \boldsymbol{c}_{\alpha}
$$

$2 \cdot 2$ 塂界条件取り扱う心゙き境界面は，領域境 界面と粒子表面上の境界面である。本研究の場合，熱力 学的平衡状態にある 2 次元系を対象としているので, 分 子動力学法で用いられる周期境界条件 ${ }^{(4,5)}$ を用いること ができる。すなわち，図 1(a)を用いると，任意の時間 $t$ において，例えば，左側の境界での粒子分布関数 $\left.f_{\alpha}(x, y, t)\right|_{\text {left }}(\alpha=0,1,2, \ldots, 8)$ が右側の境界面での粒 子分布関数 $\left.f_{\alpha}(x, y, t)\right|_{r i g h t}$ に等しいとする. 同様の処理 を上下の境界面で行う。

次に最も重要な粒子表面上の処理法について示す。 前報 ${ }^{(18)}$ では, 多粒子分散系の境界モデルとして有用と思 われるいくつかの境界条件，才なわち，YLMS 法 ${ }^{(16)}$ 上 BFL 法 ${ }^{(17)}$ を取り上げ，さらに，平衡線形 YLMS 法 ${ }^{(18)}$ 提案して検討を行った。この結果，多粒子分散系で有利 と思われる平衡線形 YLMS 法の有用性が明らかになっ た. 従って，本研究ではこの平衡線形 YLMS 法を粒子 との境界モデルとして採用することにする.

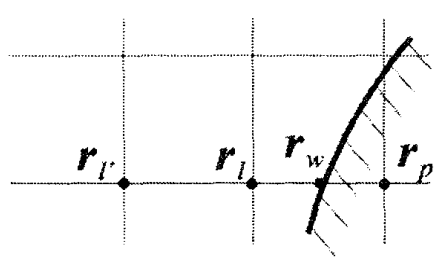

Fig.2 Equilibrium Linear Binder Model 
図 2 を用いて,格子点上のある方向の粒子分布関数に ついて考光る(図 2 の場合， $\alpha=2$ の方向). 図中の $\boldsymbol{r}_{w}$ 位粒 子表面上の点, その隣の粒子内の点を $r_{p}$, 流体側の点を $\boldsymbol{r}_{l}$, その隣の格子点を $\boldsymbol{r}_{l}$ とすれば，点 $\boldsymbol{r}_{l}$ の右側の格子点 が物体内部となってしまうので， $f_{2}\left(r_{l}, t+\Delta t\right)$ の值が式 (1)からは求まらない。屯し， $r_{w}$ の位置での粒子分布関 数 $f_{2}\left(r_{w}, t+\Delta t\right)$ が既知であるとするならば, $r_{l}$ の位置で の $f_{2}\left(\boldsymbol{r}_{i}, t+\Delta t\right)$ を用いて, $\boldsymbol{r}_{l}$ の位置での粒子分布関数 $f_{2}\left(r_{l}, t+\Delta t\right)$ が，直線を用いた内挿法により次のように 得られる.

$$
\begin{gathered}
f_{2}\left(r_{l}, t+\Delta t\right)=\frac{\Delta_{w}}{1+\Delta_{w}} f_{2}\left(r_{l^{\prime}}, t+\Delta t\right)+\frac{1}{1+\Delta_{w}} \\
\times f_{2}\left(r_{w}, t+\Delta t\right)
\end{gathered}
$$

ここに, $\Delta_{w}=\left|r_{l}-r_{w}\right| /\left|r_{l}-r_{p}\right|$ である.図 2 の場合, $\alpha=1$ に対する $\bar{\alpha}=2(\alpha=1$ の反対方向)を対象としたものであ るが，境界をまたぐ任意の方向 $\alpha$ に対する $\bar{\alpha}$ 方向に関 し, 式(5)がそのまま成り立つ。さて, 式(5)より $f_{2}\left(r_{l}, t+\Delta t\right)$ を求めるためには， $f_{2}\left(r_{w}, t+\Delta t\right)$ が必要 であるが，平衡線形 YLMS 法では， $f_{2}\left(r_{w}, t+\Delta t\right)$ とし て式(2)で示した平衡分布を用いる.

2・3 粒子に作用するカとトルク いま，粒子の すぐ外側にある任意の格子点 $\boldsymbol{r}_{i}^{c y l}$ に着目すると， $\alpha=\alpha_{l}^{c y l}$ 方向の隣の格子点が粒子内部にある上する．時 間 $t$ に抢いて粒子に向かう運動量は $c_{\alpha_{l}^{c y l}} \tilde{f}_{\alpha_{l}^{c y l}}\left(r_{l}^{c y l}, t\right) \Delta x \Delta y$ であり，時間 $(t+\Delta t)$ において粒 子と衝突後の運動量は $-c \alpha_{l}^{c y l} f_{\bar{\alpha}_{l}^{c y l}}\left(r_{i}^{c y l}, t+\Delta t\right) \Delta x \Delta y$ であ る. 運動量の変化は力積 $F_{\alpha_{t}^{c y i}} \Delta t$ に等しいので,この場 合に粒子に作用する力 $F_{\alpha c l}^{c y l}$ は次のように得られる.

$$
\begin{aligned}
& \boldsymbol{F}_{\alpha_{l}^{c y l}}=\left\{c_{\alpha_{l}^{c y l}} \tilde{f}_{\alpha_{l}^{c y l}}\left(\boldsymbol{r}_{l}^{c y l}, t\right) \Delta x \Delta y\right. \\
& \left.\quad+c_{\alpha_{l}^{c y l}} f_{\bar{\alpha}_{l}^{c y l}}\left(\boldsymbol{r}_{l}^{c y l}, t+\Delta t\right) \Delta x \Delta y\right\} / \Delta t
\end{aligned}
$$

同様に，粒子に作用するトルク $T_{\alpha_{l}^{c y l}}$ は次にように書け る.

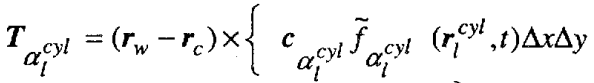

$$
\begin{aligned}
& \left.+c_{\alpha_{l}^{c y l}} f_{\bar{\alpha}_{l}^{c y l}}\left(r_{l}^{c y l}, t+\Delta t\right) \Delta x \Delta y\right\} / \Delta t
\end{aligned}
$$

ここに， $\boldsymbol{r}_{c}$ は粒子の重心の位置ベクトル， $\boldsymbol{r}_{w}$ は流体内 の格子点 $r_{l}^{(c y l)}$ から $\alpha$ 方向に延ばした直線上の粒子表面 の位置ベクトルである．また， $a$ に関する和は，物体 表面をまたぐ方向のみを対象とする。

ゆえに，流体が粒子 $i$ に作用する力 $\boldsymbol{F}_{i}{ }^{\left({ }^{(t t c)}\right.}$ および粒子 の重心まわりのトルク $T_{i}^{(t t c)}$ は, 粒子 $i$ と相互作用する す心゙ての近接格子点での和を取り，次のように得られ る.

$$
\boldsymbol{F}_{i}^{(l i t c)}=\sum_{l} \sum_{\alpha_{l}^{c y l}} F_{\alpha_{l}^{c y l}}, T_{i}^{(l t t c)}=\sum_{l} \sum_{\alpha_{l}^{c y l}} T_{\alpha_{l}^{c y l}}
$$

\section{3. 多粒子分散系の格子ボルッマン・ シミュレーション}

3-1 磁性粒子モデル 磁性粒子のモデルとし ては，中心に磁気双極子を有し，その表面を界面活性 剂よって一様に被覆された球状粒子を考える。粒子固 体部の直径を $D$, 界面活性剂層の厚さを $\delta$ とすれば, 同一径を有するこのような粒子 $i, j$ 間の磁気的な相互作 用のエネルギー $u_{i j}{ }^{(m)}$, 粒子 $i$ と印加磁場 $\boldsymbol{H}(H=|\boldsymbol{H}|)$ との 相互作用のエネルギー $u_{i}^{(H)}$, および,界面活性剤層の重 畳に起因する粒子間相互作用のエネルギー $u_{i j}{ }^{(V)}$ は, 文 献(3)に書かれているとおりである。これらのエネル ギーの式より，粒子間磁気力と印加磁場および界面活 性剂による粒子 $i$ に作用する力とトルクが次のように 得られる。

$$
\begin{aligned}
\boldsymbol{F}_{i j}^{(m)}= & -k T \lambda \frac{3}{D\left(r_{i j} / D\right)^{4}}\left[-\left(\boldsymbol{n}_{i} \cdot \boldsymbol{n}_{j}\right) \boldsymbol{t}_{i j}+5\left(\boldsymbol{n}_{i} \cdot \boldsymbol{t}_{i j}\right)\right. \\
& \left.\left.\left.\times\left(\boldsymbol{n}_{j} \cdot \boldsymbol{t}_{i j}\right) \boldsymbol{t}_{i j}\right)-\left\{\left(\boldsymbol{n}_{j} \cdot \boldsymbol{t}_{i j}\right) \boldsymbol{n}_{i}+\left(\boldsymbol{n}_{i} \cdot \boldsymbol{t}_{i j}\right) \boldsymbol{n}_{j}\right)\right\}\right] \\
\boldsymbol{F}_{i j}^{(V)}= & \frac{k T}{\delta} \lambda_{V} \boldsymbol{t}_{i j} \ln \left(D_{1} / r_{i j}\right) \quad \text { for } D \leq r_{i j} \leq D_{1} \\
T_{i j}{ }^{(m)}= & -k T \lambda \frac{1}{\left(r_{i j} / D\right)^{3}}\left\{\boldsymbol{n}_{i} \times \boldsymbol{n}_{j}-3\left(\boldsymbol{n}_{j} \cdot \boldsymbol{t}_{i j}\right) \boldsymbol{n}_{i} \times \boldsymbol{t}_{i j}\right\} \\
T_{i}^{(H)}= & k T \xi \boldsymbol{n}_{i} \times \boldsymbol{h}
\end{aligned}
$$

ここに， $\boldsymbol{F}_{i j}{ }^{(m)}$ は粒子 $j$ が粒子 $i$ に作用する磁気力, $\boldsymbol{F}_{i j}{ }^{(V)}$ は粒子 $j$ との界面活性剤の重なりにより生じる乕力, $T_{i j}^{(m)}$ 汢粒子 $j$ が磁気力によって粒子 $i$ に作用するトルク， $\boldsymbol{T}_{i}^{(H)}$ は磁気モーメントが印加磁場の方向からずれるこ とによって生じるトルクである。また， $n_{i}$ は磁気モ一 メント $\boldsymbol{m}_{i}$ の方向を表す単位ベクトルで, $n_{i}=\boldsymbol{m}_{i} / m$ $\left(m=\left|\boldsymbol{m}_{i}\right|\right), \boldsymbol{t}_{i j}$ 仗粒子 $i, j$ 間を結ぶベクトル $\boldsymbol{r}_{i j}\left(=\boldsymbol{r}_{i}-\boldsymbol{r}_{j}\right)$ の単位 ベクトル表現で, $t_{i j}=r_{i j} / r_{i j}, r_{i j}=\left|r_{i j}\right|, h=H / H, k$ はボルツマ ン定数, $T$ は液温, $D_{1}$ は界面活性剂層を含めた粒子の直 径で $D_{1}=D+2 \delta, t_{\delta}$ は粒子固体部の半径亡界面活性剂層 の厚さ $\delta$ との比で, $t_{j}=2 \delta / D$ である. 上式に現れた無次 元パラメータ $\lambda, \xi, \lambda_{V}$ は, $\lambda=\mu_{0} m^{2} /\left(4 \pi D^{3} k T\right), \quad \xi=\mu_{0} m H / k T$,

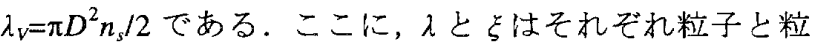
子，粒子と磁場之の磁気的な相互作用の大きさを表す 無次元パラメータ, $\lambda_{V}$ は界面活性剂層の重疊に起因す る斥力の大きさを表す無次元パラメータ， $\mu_{0}$ は真空の 透磁率， $n_{s}$ は粒子表面の単位面積当たりの界面活性剤 分子の数である.

結局，任意の粒子 $i$ に作用する力とトルクは次のよ うになる。

$$
\begin{aligned}
& F_{i}=\sum_{j(\neq i)}\left(F_{i j}^{(m)}+F_{i j}^{(V)}\right)+F_{i}^{(l t t c)} \\
& T_{i}=\sum_{j(\neq i)}\left(T_{i j}^{(m)}+T_{i j}^{(H)}\right)+T_{i}^{(l t t c)}
\end{aligned}
$$




\section{3・2 磁性粗子の通動方程式磁性粒子の質量} を $M$, 慣性モーメントを $I$ とすると, ニュートンの運 動方程式より，任意の粒子 $i$ の位置ベクトル $\boldsymbol{r}_{i}$ および 速度 $\boldsymbol{v}_{i}$ は次式のように得られる。

$$
\begin{aligned}
& r_{i}(t+\Delta t)=r_{i}(t)+\Delta t v_{i}(t)+\frac{(\Delta t)^{2}}{2 M} F_{i}(t) \\
& v_{i}(t+\Delta t)=v_{i}(t)+\frac{\Delta t}{M} F_{i}(t)
\end{aligned}
$$

同様に，角速度 $\omega_{i}$ および粒子方向(磁気モーメントの 方向) $\boldsymbol{n}_{i}$ は次のようなる。

$$
\begin{aligned}
& n_{i}(t+\Delta t)=n_{i}(t)+\Delta t \omega_{i}(t) \times n_{i}(t) \\
& \omega_{i}(t+\Delta t)=\omega_{i}(t)+\frac{\Delta t}{I} T_{i}(t)
\end{aligned}
$$

3.3 年次元化 シミュレーションに際しては， 諸量を無次元化した無次元系を対象とする.時間を $\Delta t$, 距離を $\Delta x$, 速度を $c(=\Delta x / \Delta t)$, 粒子分布関数を $\rho_{0}$, 力を $\rho_{0}(\Delta x)^{2} \Delta x /(\Delta t)^{2}$ などで無次元化する．粒子分布関数の 基礎方程式(1)に関する無次元表示洨容易に表せるの で，ここでは磁性粒子に関係する無次元表示を示す。

磁性粒子関係の無次元表示は次の上うに書ける。

$$
\begin{aligned}
\boldsymbol{F}_{i j}^{(m)^{*}=} & -R_{m} \frac{1}{\tilde{r}_{i j}^{4}}\left[-\left(\boldsymbol{n}_{i} \cdot \boldsymbol{n}_{j}\right) \boldsymbol{t}_{i j}+5\left(\boldsymbol{n}_{i} \cdot t_{i j}\right)\right. \\
& \left.\left.\left.\times\left(\boldsymbol{n}_{j} \cdot \boldsymbol{t}_{i j}\right) \boldsymbol{t}_{i j}\right)-\left\{\left(\boldsymbol{n}_{j} \cdot \boldsymbol{t}_{i j}\right) \boldsymbol{n}_{i}+\left(\boldsymbol{n}_{i} \cdot t_{i j}\right) \boldsymbol{n}_{j}\right)\right\}\right] \\
\boldsymbol{F}_{i j}{ }^{(V)^{*}}= & R_{V} \boldsymbol{t}_{i j} \ln \left(\tilde{D}_{1} / \tilde{r}_{i j}\right) \quad \text { for } 1 \leq \tilde{r}_{i j} \leq \tilde{D}_{1} \\
\boldsymbol{T}_{i j}^{(m)^{*}}= & -R_{m} \frac{D^{*}}{3} \cdot \frac{1}{\tilde{r}_{i j}^{3}}\left\{\boldsymbol{n}_{i} \times \boldsymbol{n}_{j}-3\left(\boldsymbol{n}_{j} \cdot \boldsymbol{t}_{i j}\right) \boldsymbol{n}_{i} \times \boldsymbol{t}_{i j}\right\} \\
\boldsymbol{T}_{i}^{(H)^{*}}= & R_{H} \boldsymbol{n}_{i} \times \boldsymbol{h}
\end{aligned}
$$

ここに，*を付した量が無次元量, $\tilde{r}_{i j}=r_{i j} / D, \tilde{D}_{1}=D_{1} / D$, 無次元パラメータ $R_{m}, R_{V}, R_{H}$ の表式は後に示す.

磁性粒子の運動方程式の無次元表示は次の上うにな る.

$$
\begin{aligned}
& r_{i}^{*}\left(t^{*}+1\right)=r_{i}^{*}\left(t^{*}\right)+v_{i}^{*}\left(t^{*}\right)+\frac{2}{\pi \rho_{p}^{*} D^{* 2}} F_{i}^{*}\left(t^{*}\right) \\
& v_{i}^{*}\left(t^{*}+1\right)=v_{i}^{*}\left(t^{*}\right)+\frac{4}{\pi \rho_{p}^{*} D^{* 2}} F_{i}^{*}\left(t^{*}\right) \\
& n_{i}\left(t^{*}+1\right)=n_{i}\left(t^{*}\right)+\omega_{i}\left(t^{*}\right) \times n_{i}\left(t^{*}\right) \\
& \omega_{i}^{*}\left(t^{*}+1\right)=\omega_{i}^{*}\left(t^{*}\right)+\frac{32}{\pi \rho_{p}^{*} D^{* 4}} T_{i}^{*}\left(t^{*}\right)
\end{aligned}
$$

式(23),(24),(26)の導出に際して, 円形粒子を仮定するこ とで，磁性粒子の質量 $M$ と慣性モーメント $I$ を磁性粒 子の密度と直径の関数で表した。すなわち, $M=\rho_{p} \pi D^{2} / 4$, $I=\rho_{p} \pi D^{4} / 32$ として, 支配要因を一つ隇らして簡単化し たことになる．
最後に，無次元パラメータ $R_{m}, R_{V}, R_{H}$ の表式を示す. 本研究では熱力学的平衡状態を対象としているので, エネルギー等分配則より，仮想流体粒子の運動エネル ギーの平均值を系の温度 $T$ と関係付けることができる. 格子ボルツマン法の理論より, $k T=m_{0} c^{2} / 3\left(m_{0}\right.$ は 1 格子 当たりの仮想流体粒子の質量)なる関係があることが わかるので，この関係式を考慮すると，無次元パラ メータの表示が次のように得られる.

$$
R_{m}=\frac{1}{D^{*}} \lambda, R_{V}=\frac{1}{3 \delta^{*}} \lambda_{V}, R_{H}=\frac{1}{3} \xi
$$

\section{4. シミュレーションのための䯈量の設定}

シミュレーションで詳細に検討するために，以下の ような諸量の值を設定した。磁性粒子の無次元密度 $\rho_{p}{ }^{*}$ を $\rho_{p}{ }^{*}=3,5,7,10$ の 4 通りに, 無次元直径 $D^{*}$ を $D^{*}=4,6$, 8,15 の 4 通りに取っている.緩和時間 $\tau$ は $\tau=0.7$ とし, 磁性粒子の体積分率 $\phi_{v}$ は $\phi_{V}=0.2$ の一通りとし, 磁性粒 子の粒子数 $N_{p}$ は, $D^{*}=15$ という非常に細かい格子も検 討するので, $N_{p}=100$ という比較的小さな系を対象と した. 過去のモンテカルロ法やブラウン動力学法の結 果 ${ }^{(19-21)}$ と比較するために，界面活性郕による相互作用 の大きさ $\lambda_{V}$ を $\lambda_{V}=150$, 粒子間の磁気的な相互作用の 大きさ $\lambda$ 老 $\lambda=0 \sim 15$, 磁性粒子と磁場との相互作用の大 きさ $\xi を \xi=0 \sim 20$ と幅広く設定した. 磁性粒子間の力を 求めるためのカットオフ距離 $\tilde{r}_{\text {coff }}\left(=r_{\text {coff }} / D\right)$ は $\tilde{r}_{\text {coff }}=7.0$ を採用し，総時間ステップ数 $N_{\text {timem } x}$ は $N_{\text {timemx }}=200,000$ として，初期の 1 割のステップ数での值を除いた值を 用いて平均操作を行った。

\section{5. 䊅果と考察}

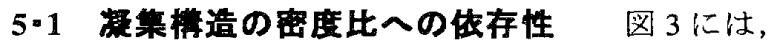
まわりの流体粒子と磁性粒子の密度比 $\rho_{p}{ }^{*}$ が磁性粒子 の凝集構造にどのように影響するかを見るために，粒 子值径(格子粗さ)を $D^{*}=8$ として, 磁場の強さを $\xi=5$, 粒子間の磁気的な相互作用の大きさを $\lambda=5$ とした場合 の凝集構造の結果が示してある。図 3(a) は密度比を $\rho_{p}{ }^{*}=3$ とした場合, 図 3(b)は $\rho_{p}{ }^{*}=10$ とした場合の結果で ある. $\xi=1 ， \lambda=1$ の凝集構造は, 後に示す図 4(a) とほと んど定性的に同じスナップショットなので図には示し ていない． $\xi=\lambda=1$ の場合, 磁場も粒子間磁気力もブラ ウン運動を誘起するランダム力と同程度なので, 粒子 は単独で運動し, 顕著な凝集体を形成していない. 図 3 の $\xi=\lambda=5$ の場合, 磁場方向に細い鎖状クラスタを形 成しており，この環境下では粒子間磁気力も印加磁場 の影響もランダム力よりもかなり支配的なので，鎖状 クラスタの形成は物理的に妥当な結果である(19-21). ま 
$a$

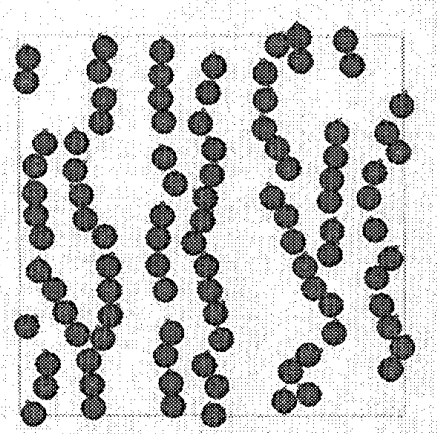

$b$

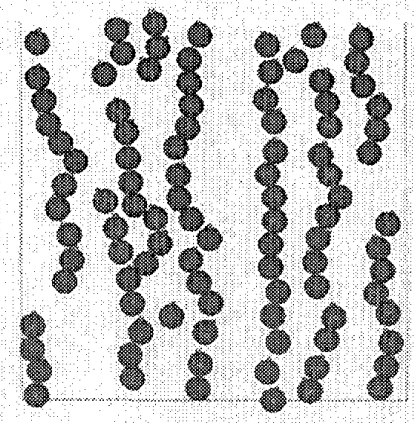

Fig. 3 Dependence of Aggregate Structures on Density Ratio $\rho_{p}{ }^{*}$ for $\xi=\lambda=5\left(D^{*}=8\right)$ : (a) $\rho_{p}{ }^{*}=3$ and (b) $\rho_{p}^{*}=10$ $a$

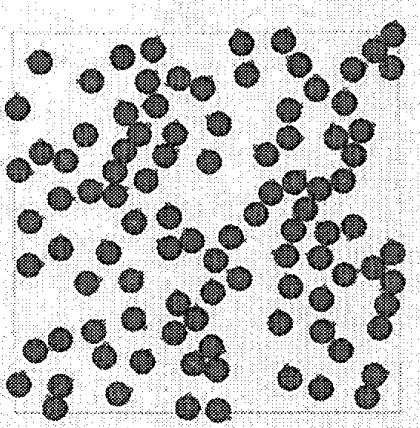

$\boldsymbol{b}$

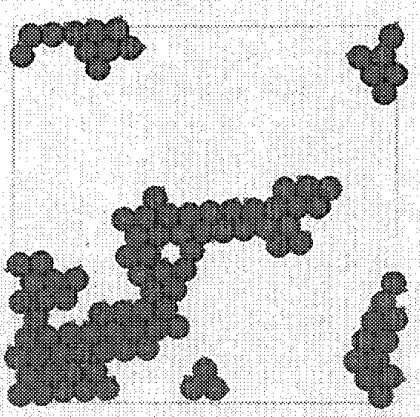

Fig.4 Dependence of Aggregate Structures on the Fineness of the Lattice for $\xi=\lambda=1 \quad\left(\rho_{p}{ }^{*}=5\right)$ :

(a) $D^{*}=8$ and (b) $D^{*}=15$ $a$

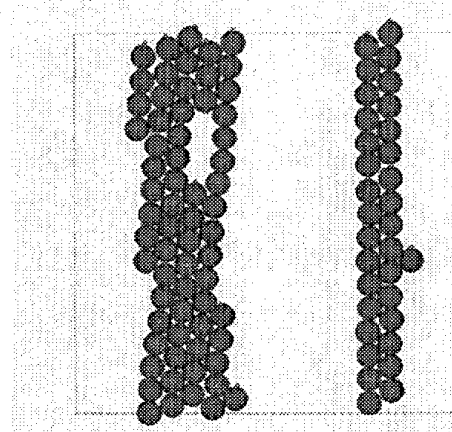

$b$

Fig.5 Dependence of Aggregate Structures on the Fineness of the Lattice for $\xi=\lambda=10\left(\rho_{p}{ }^{*}=5\right)$ : (a) $D^{*}=8$ and (b) $D^{*}=15$

た, 先の $\xi=\lambda=1$ の場合と同様に, 密度比に依存して凝 集構造が大きく異なることはない。このように，ブラ ウン運動は妥当なレベルで誘起されている.

5・2 准集權の佫子粗さへの依存性前項での 結果から，凝集構造は密度比にほとんど依存しないこ とがわかったので，磁性粒子が金属粒子であることを 考慮して $\rho_{p}{ }^{*}=5$ に限定し，凝集構造に及ぼす格子粗さ の影響を検討する。図 4 法 $\xi=\lambda=1$ の場合の凝集構造の 結果であり， $D^{*}=8,15$ の 2 通りの格子粗さの結果が示 してある.なお, 無次元粒子直径 $D^{*}$ の值が小さいほど 格子は粗くなる.同様の結果を $\xi=\lambda=10$ に対して図 5 に 示す. $\xi=\lambda=1$ の場合, 粒子間磁気力や印加磁場の影響 がブラウン運動と同程度なので, 粒子の凝集は生じな いはずである(19-21). 図 4(a)の $D^{*}=8$ の場合には, 粒子の 凝集は生じておらず, 物理的に妥当な結果を与えてい る。ところが， $D^{*}=15$ のように非常に緻密な格子を用 いた結果は，粒子が凝集し大きな塊のクラスタをいく つか形成するという，物理的にあり得ない凝集構造を 与えてしまっている。このことは， $D^{*}=15$ のような緻 密な格子を用いると, 粒子のブラウン運動が誘起され ないことを如実に示している。また，これは粒子間磁 気力と印加磁場が熱連動よりも十分支配的な図 5 にお いてもはっきりと示されている. 強磁場中において，

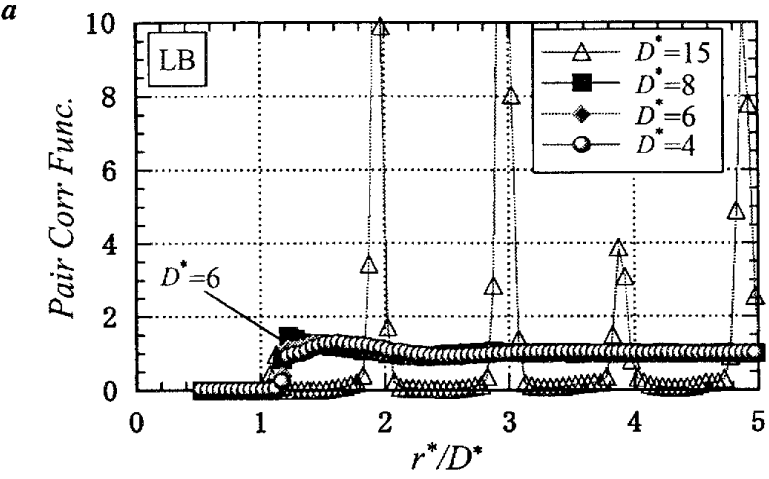

$b$

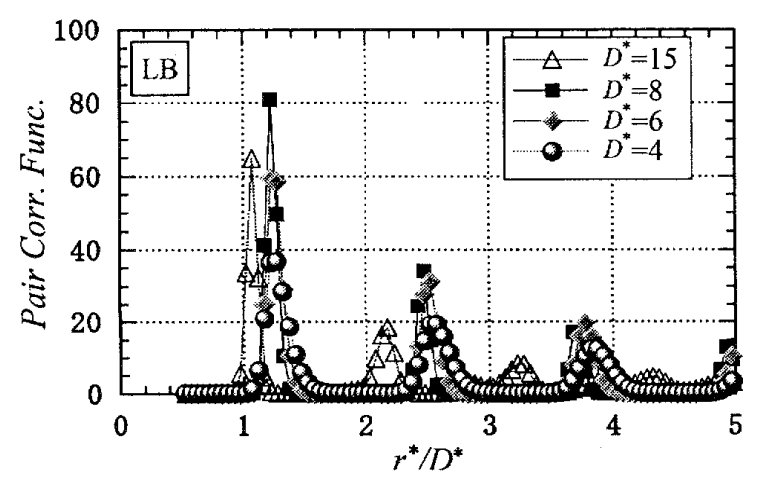

Fig. 6 Pair Correlation Function for $\rho_{p}{ }^{*}=5$ : (a) $\xi=\lambda=1$ and (b) $\xi=\lambda=10$ 
$a$

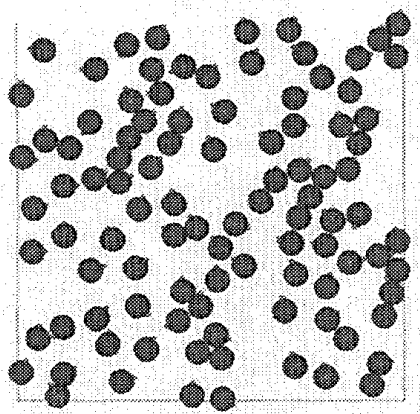

$d$

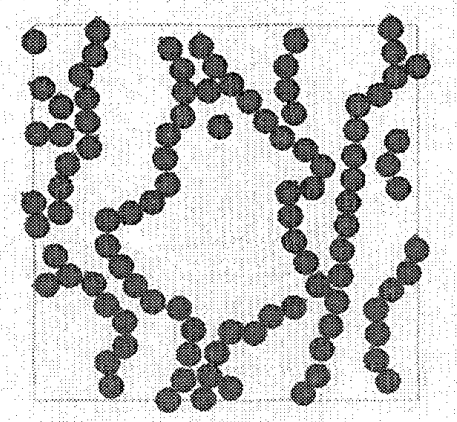

$b$

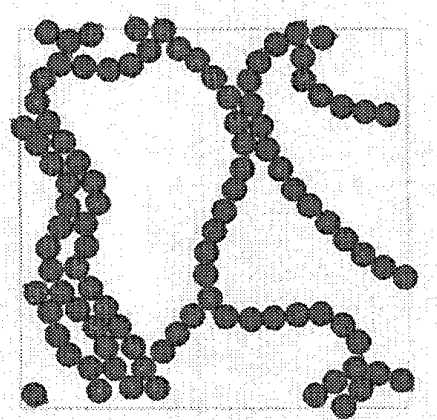

$\boldsymbol{e}$

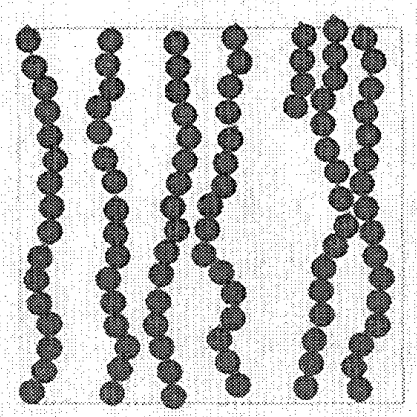

c

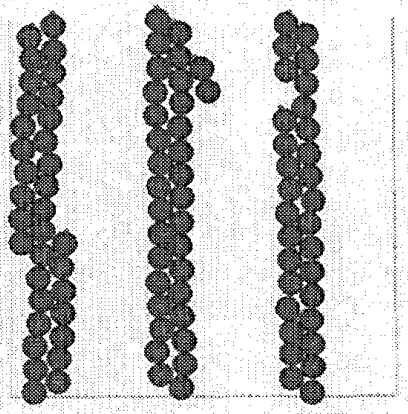

$f$

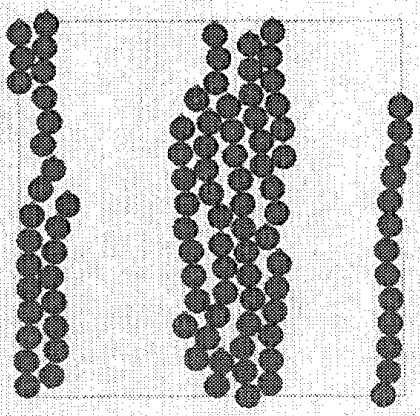

Fig.7 Comparison of Lattice Boltzmann (LB) Results with Monte Carlo (MC) and Brownian Dynamics (BD) ones: (a) $\xi=\lambda=1, \mathrm{LB}$; (b) $\xi=1$ and $\lambda=10, \mathrm{LB}$; (c) $\xi=20$ and $\lambda=10$, LB; (d) $\xi=1$ and $\lambda=10$, MC; (e) $\xi=20$ and $\lambda=10$, MC;

(f) $\xi=\infty$ and $\lambda=10, \mathrm{BD}$

粒子間磁気力がランダム力と比較してそれほど圧倒的 に大きくない場合，磁場方向に太い鎖状クラスタを形 成することが，モンテカルロ法やブラウン動力学法に よってすでに指摘されているが(19-21)， $D^{*}=8$ の場合の結 果汇，まさしくこのような太い鎖状クラスタの形成を 妥当な形で再現することに成功している，ところが， 図 5(b)の $D^{*}=15$ の場合, 先の図 4(b)と同じように, 大 きな一塊のクラスタの形成を与えてしまって抢り, 全 く正しくない凝集構造の結果となっている.

$5 \cdot 32$ 体相関関数の格子粗さへの惊存性 前項 の凝集構造を 2 体相関関数を用いて定量的に議論する. 格子粗さを $D^{*}=4,6,8,15$ と取って得た磁場方向の 2 体 相関関数の結果を図 6 に示す、図 6(a) は $\xi=\lambda=1$ の場合 の結果, 図 6(b)は $\xi=\lambda=10$ の場合の結果である. 図 6(a) からわかるように, $D^{*}=4,6,8$ の場合はほぼ一致してお り, 気体的な特徵を示している. すなわち, 粒子が凝 集しないことを定量的に裏付けている. 一方， $D^{*}=15$ の結果は粒子直径のほほ整数倍の位置に非常に高い ピークを有して，その間はほぼゼロの值を取っている ことから，まさしく固体的な特徵を有している.ゆえ に，図 4(b)に示した凝集構造の内部構造注固体のよう に結合して非常に安定しているということになる。こ のように, $D^{*}=15$ の場合ブラウン運動が誘起されない
ことが，2 体相関関数の結果からも裏付けられた。図 6(b)の場合，磁場方向に太い鎖状クラス夕を形成する ので, $D_{1}{ }^{*}$ のほ整数倍の位置にピークが生じるのは物 理的に妥当な結果であり, $D^{*}=4,6,8$ の場合, ほぼ同じ 位置にピークが生じるという満足できる一致を示して いる，ただし，粒子が近接状態に近くなる第 1 ピーク は，D*の值によってばらつきがあり，D*の值が増すほ どピーク值が高くなる傾向があるように見受けられる。 $D^{*}=15$ の場合は，図 5(b)からかかるように，磁場方向 に鎖状クラスタを形成せず，大きな一塊のクラスタを 形成するので, 他の場合と異なる位固でピーク值を与 えている。すなわち, ブラウン運動が誘起されないの で, このような間違った 2 体相関関数の結果を当然与 えてしまうことになる.なお，D*のどのくらいの值ま で,ブラウン運動が物理的に妥当なレベルで誘起され るかは，Landau-Lifshitz の理論に基づいた基礎式の修 正を行うことで, 現在研究が進展している段階である.

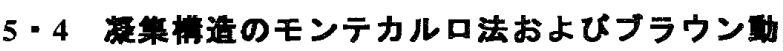
力学法との比较 ここから，格子ボルツマン法の結 果をモンテカルロ法とブラウン動力学法により得た結 果と比較することにより，多粒子分散系に対する格子 ボルツマン法の有効性を検討する、前項までの結果か ら，格子ボルツマン法の結果としてはす心゙て $\rho_{p}{ }^{*}=5$, 
$a$
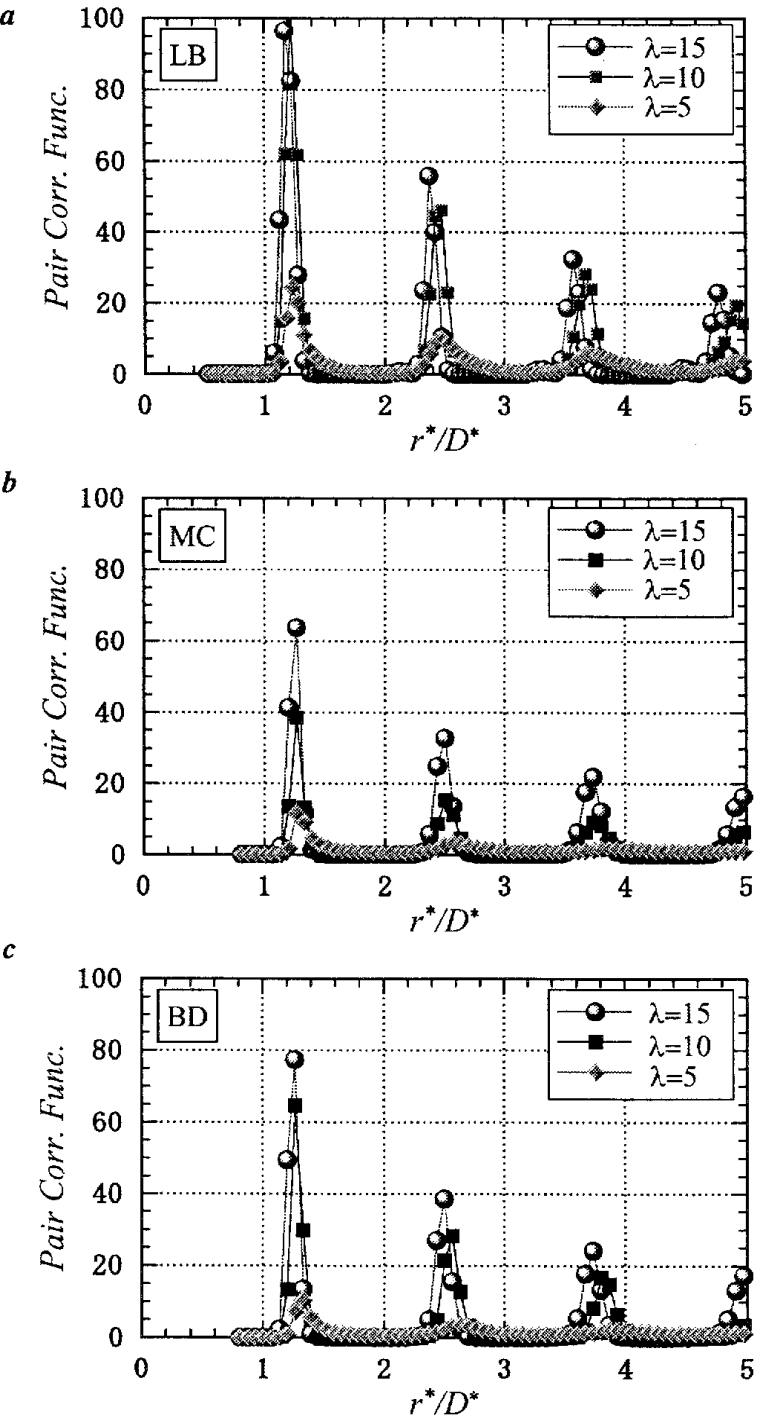

Fig. 8 Pair Correlation Function for (a) $\xi=20$, LB, (b) $\xi=20, \mathrm{MC}$, and (c) $\xi=\infty, \mathrm{BD}$

$D^{*}=8$ の場合に得た結果を対象とする。図 7 は凝集構造 のスナップショットで，図 7(a),(b),(c)は格子ボルツマ ン法の結果であり，図 7(a) は $\xi=\lambda=1$ の場合の結果であ る.図 7(b),(c) はそれぞれ $\zeta=1, \lambda=10$ の場合と $\xi=20, \lambda=10$ の場合で, 同様の条件下におけるモンテカルロ法の結 果 ${ }^{(19)}$ が, 図 7(d),(e)に相当する. 図7(f)は $\xi=\infty, \lambda=10$ の 場合に対するブラウン動力学法の結果 ${ }^{(21)}$ である.

まず, $\xi=1$ の場合の結果である図7(a)はモンテカルロ 法の結果(図には示していない)と定性的にまったく一 致する。同様に，図 7(b)と図 7(d)を比較すると，定性 的に非常によい一致を示していることがわかる。すな わち，粒子間相互作用が弱い $\lambda=1$ の場合には粒子は凝 集せず単独で運動しているが， $\lambda$ の值が増すに従って，

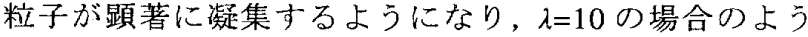
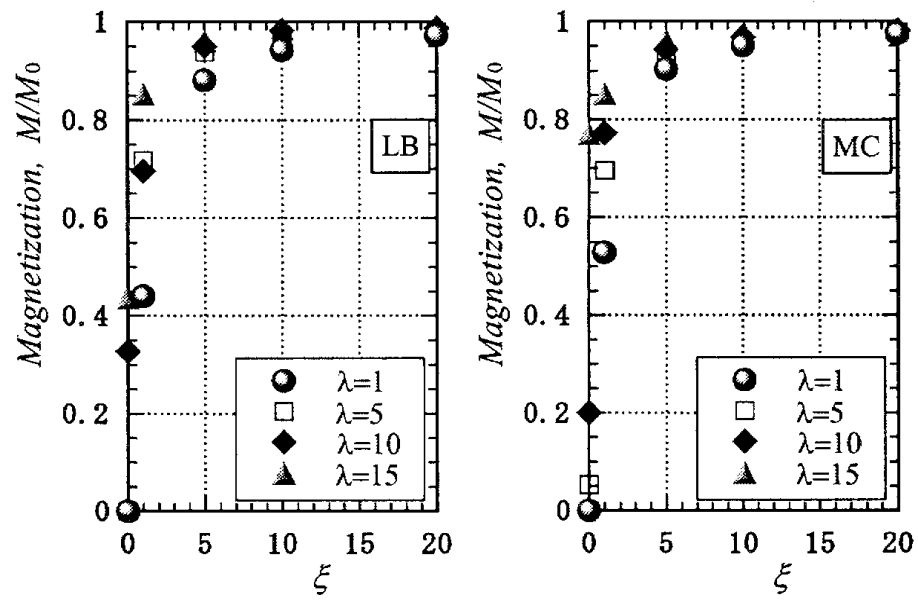

Fig.9 Magnetization Curves for (a) LB and (b) MC

にブラウン運動に対して粒子間磁気力が非常に支配的 な場合には, ネックレス状の凝集体が形成されている. このように格子ボルッマン法でも磁性粒子のブラウン 運動が適切に誘起されていることがわかる。

次に, 強磁場の場合である図 7(c),(e),(f)のスナップ ショットを考察する。この場合も結果は比較的よく一 致するが，先の磁場の弱い場合ほよ゙ではない， $\lambda=100$ ように粒子間磁気力が大きくなるほど，太い鎖状クラ スタを形成するようになるが，格子ボルツマン法とブ ラウン動力学法の結果は, ほぼ定性的に一致するクラ スタ形成を得ている。一方, モンテカルロ法の太い鎖 状クラスタは他の方法の結果ほど密な状態とはなって いない。これは格子ボルツマン法やブラウン動力学法 が，モンテカルロ法よりも精度が落ちる結果を与えて いるものではなく，逆にモンテカルロ法の弱点を示し ているものである。すなわち，格子ボルツマン法やブ ラウン動力学法法粒子の多体流体力学的な相互作用を 考慮した方法であるのに対して，モンテカルロ法はそ のような流体力学的な相互作用を考慮したシミュレ一 ション法ではない,

5-5 2 体相関関数および硬化曲稳のモンテカルロ 法およぴフラウン功力学法との比较最後に, 前項 の凝集構造を 2 体相関関数および磁化曲線を用いて定 量的な議論を行う. 図 8(a), (b), (c)はそれぞれ格子ボル ツマン法, モンテカルロ法, ブラウン動力学法により 得た磁場方向の 2 体相関関数の結果である. 図 8(a),(b) は $\xi=20$ 場合の結果であり，図 8(c)は $\xi=\infty$ の場合の結 果である. 粒子間相互作用を $\lambda=5,10,15$ のように比較 的大きく取っているので，磁場方向に鎖状クラスタを 形成することは, 前項の凝集構造のスナップショット 
で見たとおりである，ゆえに，3者とも，粒子直径 $D_{1}{ }^{*}$ の整数倍の位置(綮密に沙少しそれより近距離)でピー クが生じている。ピークの高さも，満足できる一致を 示していると言うこともできるが，傾向として，モン テカルロ法の結果が各ピーク上も一番低く，次がブラ ウン動力学法の結果, 格子ボルツマン法の結果が各 ピークとも最も高いピーク值を示している，先のス ナップショットの結果から，モンテカルロ法では粒子 の流体力学的な相互作用を考慮していないので，流体 力学的な相互作用を考慮すると，より安定した太い鎖 状クラスタを形成するはずである。中えに，格子ボル ツマン法やブラウン動力学法の結果がモンテカルロ法 よりも高いピーク值を示すのは物理的に妥当である。 また, ブラウン動力学法の結果 ${ }^{(21)}$ は遠距離の流体力学 的な相互作用を考慮していないことから，格子ボルツ マン法の結果がブラウン動力学法の結果より高いピー ク值を示古のも納得できる，以上を考慮すると，本格 子ボルツマン法は物理的に最も道理にかなった結果を 与えているものと結論付けられる。

最後に，磁化曲線の結果である図 9 を考察する。図 9(a)は格子ボルッマン法の結果で，図 9(b)はモンテカ ルロ法の結果である， $\lambda=1$ の磁化曲線を見る上，格子 ボルツマン法の結果はモンテカルロ法の結果とよく一 致しており，特にほ二0で磁化の強さがゼロとなってい る。これは，格子ボルツマン法が粒子の回転ブラウン 運動を物理的に妥当な形で誘起するこ上を示すすので

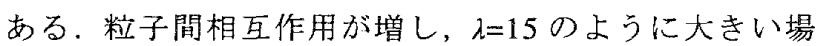
合でも，モンテカルロ法とよく一致している。このよ うに，粒子間相互作用が大きくなっても，粒子の回転 ブラウン運動が正しく誘起されることがわかる。

\section{6. 结}

本研究では，粒子の多体流体力学的相互作用を考慮 したシミュレーション法としての格子ボルツマン法の 可能性を，2 次元系の磁性粒子からなるサスペンショ ン系の凝集現象に着目して検討した。得られた結果を 要約すると以下のようになる。比較的粗い格子を用い た場合，通常の格子ボルツマン法でも，粒子の並進お よび回転のブラウン連動が物理的に妥当な形で誘起さ れる。一方，緻密な格子を用いた場合，粒子のブラウ ン運動が誘起されず，間違った凝集構造を与えてしま う。従って，緻密な格子を用いる場合，従来の格子ボ ルツマン法の基礎方程式に何らかの修正が必要である。
本研究の一部は文部科学省の科学研究費補助金・基 盤研究 B(20360048)の補助を受けてなされた。ここに付 記して謝意を表する。

\section{女}

(1) R.B. Bird, R.C. Armstrong and O. Hassager, Dynamics of Polymeric Liquids, Vol.1, Fluid Mechanics, (1987), John Wiley \& Sons.

(2) W.B. Russel, D.A. Saville and W.R. Schowalter, Colloidal Dispersions, (1989), Cambridge University Press.

(3) A. Satoh, Introduction to Molecular-Microsimulation of Colloidal Dist ersions, (2003), Elsevier Science.

(4) M.P. Allen and D.J. Tildesley, Computer Simulation of Liquids, (1987), Clarendon Press.

(5) S. Kamiyama and A. Satoh, Molecular Dynamics Simulation, (1997), Asakura Shuppan. (Japanese)

(6) H.G. Choi and D.D. Joseph, University of Minesota Supercomputing Institute Research Report, UMSI 2000/17, February 2000.

(7) R. Glowinski, T.W. Pan, T.I. Hela, D.D. Joseph and J.A. Priaux, University of Minesota Supercomputing Institute Research Report, UMSI 2000/68, April 2000.

(8) C. Diaz-Goano, P.D. Minev and K. Nandakumar, J. Comp. Phys.,Vol. 192, (2003), pp. 105-123.

(9) P.J. Hoogerbrugge and J.M.V. A. Koelman, Europhysics. Letters, Vol. 19, (1992), pp.155-160.

(10) P. Espanol and P. Warren, Europhysics Letters, Vol. 30 (1995), pp. 191-196.

(11) A. Satoh and T. Majima, Transaction of the Japan Society of Mechanical Engineers, Series B, Vol. 70, No. 694 (2004), pp. 1473-480.

(12) A. Satoh and T. Majima, Transaction of the Japan Society of Mechanical Engineers, Series B, Vol. 70, No. 695 (2004), pp. 1657-1664.

(13) A. Satoh and R.W. Chantrell, Transaction of the Japan Society of Mechanical Engineers, Series B, Vol. 72, No. 721 (2006), pp.2226-2234.

(14) S. Succi, The Lattice Boltzmann Equation for Fluid Dynamics and Beyond, (2001), Clarendon Press.

(15) D.H. Rothman and S. Zaleski, Lattice-Gas Cellular Automata, Simple Models of Complex Hydrodynamics, (1997), Cambridge University Press.

(16) D. Yu, R. Mei, L.-S. Luo and W. Shyy, Prog. Aerospace Sci., Vol. 39, (2003), pp.329-367.

(17) M. Bouzidi, M. Firdaouss and P. Lallemand, Phys. Fluids, Vol.13, (2001), pp. 3452-3459.

(18) A. Satoh and R.W. Chantrell, Transaction of the Japan Society of Mechanical Engineers, Series B. (submitted)

(19) A. Satoh, R.W. Chantrell, S. Kamiyama and G.N. Coverdale, Transactions of the Japan Society of Mechanical Engineers, Series B, Vol.61, No.583, (1995), pp.926-932.

(20) A. Satoh, R.W. Chantrell, S. Kamiyama and G.N. Coverdale, Transactions of the Japan Society of Mechanical Engineers, Series B, Vol.61, No.588, (1995), pp.2961-2967.

(21) A. Satoh, R.W. Chantrell and G.N. Coverdale, Transactions of the Japan Society of Mechanical Engineers, Series B, Vol.64, No.620, (1998), pp.1033-1040. 